\title{
Experimental and Modeling Study of CO-Selective Catalytic Reduction of NO Over Perovskite-Type Nanocatalysts
}

\author{
Shiva Abedi ${ }^{1}$ Aligholi Niaei ${ }^{2 *}$, Najaf Namjou², Darioush Salari², Ali Tarjomannejad², \\ Behrang Izadkhah² \\ ${ }^{1}$ Department of Chemistry, Faculty of Science, Urmia University, $11 \mathrm{~km}$ Sero Road, Urmia, 5756151818, Iran \\ 2 Department of Chemical Engineering and Applied Chemistry, Faculty of Chemistry, University of Tabriz, \\ 29 Bahman Blvd. Tabriz, 5166616471, Iran \\ * Corresponding author, e-mail: a.niaei@tabrizu.ac.ir
}

Received: 21 January 2019, Accepted: 04 April 2019, Published online: 15 May 2019

\begin{abstract}
In this work $\mathrm{LaFeO}_{3}, \mathrm{LaFe}_{0.7} \mathrm{Mn}_{0.3} \mathrm{O}_{3}$ and $\mathrm{LaMn}_{0.7} \mathrm{Fe}_{0.3} \mathrm{O}_{3}$ nanocatalysts with perovskite structures have been synthesized by sol-gel method. The selective catalytic reduction of $\mathrm{NO}$ with $\mathrm{CO}$ (CO-SCR) using synthesized nanocatalysts was investigated in a plug flow reactor. The kinetics of CO-SCR process was studied and three kinetic models were used to describe the behavior of the system, including power low model (PLM), kinetic model 1 (KM1) and kinetic model 2 (KM2). The KM1 was the best model with correlation coefficients of 0.9924 , 0.9911 and 0.9902 and the sum of squared errors of $0.0504,0.0488$ and 0.0397 , for $\mathrm{LaFeO}_{3^{\prime}} \mathrm{LaFe}_{0.7} \mathrm{Mn}_{0.3} \mathrm{O}_{3}$ and $\mathrm{LaFe}_{0.3} \mathrm{Mn}_{0.7} \mathrm{O}_{3}$ catalysts, respectively. By comparing experimental results with the predicted results of the KM1, it was found that the proposed model can predict the performance of catalysts in the CO-SCR process with considerable precision. The structure and morphology of perovskite-type oxides were characterized by means of X-ray diffraction (XRD) and scanning electron microscopy (SEM), respectively.
\end{abstract}

Keywords

NOx, CO-SCR, kinetic modeling, perovskite-type oxides

\section{Introduction}

One of the main sources of air pollution is the combustion of fossil fuels, which leads to the emission of toxic gases [1]. The most important emissions from combustion of fossil fuel are nitrogen oxides $\left(\mathrm{NO}_{\mathrm{x}}\right)$, sulfur oxides $\left(\mathrm{SO}_{\mathrm{x}}\right)$, carbon monoxide (CO), volatile organic compounds (VOC) and particulate matter which discharged into the atmosphere through the exhaust of cars, factories and power plants $[2,3]$. Generated $\mathrm{NO}_{x}$ in the combustion process generally refers to a mixture of $\mathrm{NO}$ and $\mathrm{NO}_{2}$ [4-7]. Emissions of nitrogen oxides are great concern for human life and environment because of acid rain and photochemical smog formation, global warming due to the greenhouse gas effects, and the depletion of the stratospheric ozone layer [5, 8-11].

In addition, producers of these gases are increasing every day [12]. The control of emissions of toxic gases such as emitted $\mathrm{NO}_{\mathrm{x}}$ from mentioned sources has become a very important issue. Among different pollutant removal methods, selective catalytic reduction (SCR) using $\mathrm{CO}$ as the reducing agent has been found effective and attractive method $[13,14]$. The use of $\mathrm{CO}$ as a reducing agent has benefits for practical applications. One important reason is presence of $\mathrm{CO}$ in automobile exhausts in significant amounts, In addition, $\mathrm{CO}$ is a poisonous gas and there are strict government regulations for $\mathrm{CO}$ emissions. Use of $\mathrm{CO}$ as reducing agent in SCR process of $\mathrm{NO}$ leads to the control of two important pollutants simultaneously in mobile sources especially in the automobile industry. In CO-SCR, CO is oxidized and NO is reduced to harmless or less harmful $\mathrm{CO}_{2}$ and $\mathrm{N}_{2}$ respectively [14].

Perovskites were used widely for SCR process due to their high catalytic activity and thermal stability; also these catalysts can be synthesized easily with acceptable cost [1, 15-17]. Perovskite-type mixed oxides have a general formula of $\mathrm{ABO}_{3}$, where $\mathrm{A}$ is lanthanide and/or alkaline earth metal ion, $\mathrm{B}$ is a transition metal ion and $\mathrm{O}$ is oxygen atom [17-19]. Multicomponent oxides of perovskite can be formed by partially substitution of A and $B$ with other elements. Partial substitution of the B site influences the catalytic activity and stability of the crystalline structure $[13,18]$. 
The aims of this research are including; preparation and characterization of perovskite nanocatalysts with formula of $\mathrm{LaFeO}_{3}, \mathrm{LaFe}_{0.7} \mathrm{Mn}_{0.3} \mathrm{O}_{3}$ and $\mathrm{LaMn}_{0.7} \mathrm{Fe}_{0.3} \mathrm{O}_{3}$ by sol-gel method, evaluation of the synthesized catalyst activity in CO-SCR process for reduction of NO in a plug flow reactor, and finally kinetic modeling of process. Based on our knowledge, the modeling of CO-SCR process using the under study catalysts in the plug flow reactor was performed for the first time in this work.

\section{Experimental}

\subsection{Catalysts preparation}

Perovskite nanocatalysts with formula of $\mathrm{LaFeO}_{3}$, $\mathrm{LaFe}_{0.7} \mathrm{Mn}_{0.3} \mathrm{O}_{3}$ and $\mathrm{LaMn}_{0.7} \mathrm{Fe}_{0.3} \mathrm{O}_{3}$ were prepared by solgel method. Low reaction temperature and well-crystalized nanocatalysts with high surface area are the main advantages of sol-gel method [20]. For preparation of catalysts suitable amounts of $\mathrm{Fe}\left(\mathrm{NO}_{3}\right)_{3} \cdot 9 \mathrm{H}_{2} \mathrm{O}$ (Merck), $\mathrm{La}\left(\mathrm{NO}_{3}\right)_{3} \cdot 6 \mathrm{H}_{2} \mathrm{O}$ (Merck) and $\mathrm{Mn}\left(\mathrm{NO}_{3}\right)_{2} \cdot 4 \mathrm{H}_{2} \mathrm{O}$ (Merck) based on stoichiometry, were dissolved in distilled water to get a sol and the obtained solution was stirred vigorously using magnetic stirrer. The solution was heated on a hot plate; when the temperature of the solution was raised to $70{ }^{\circ} \mathrm{C}$, a suitable amount of citric acid $\left(\mathrm{C}_{6} \mathrm{H}_{8} \mathrm{O}_{7} \cdot \mathrm{H}_{2} \mathrm{O}\right)$ (Merck) was added and temperature was justified at $80{ }^{\circ} \mathrm{C}$ to evaporate the water. During the dehydration process a polycondensation reaction carried out between nitrate ions and citric acid leading to formation of gel. When the gel was formed, the temperature was raised to $200{ }^{\circ} \mathrm{C}$ to burn the organic contents and reaction products turned into the dark powder. The obtained powder was calcined at $700{ }^{\circ} \mathrm{C}$ and was cooled slowly to room temperature and stored for applications [21].

$\mathrm{X}$-ray diffraction (XRD) was used to study the crystallite structure and to determine the crystallite size using Scherer equation. XRD analysis were performed using Siemens D500 diffractometer with a $\mathrm{Cu} \mathrm{K} \alpha$ radiation at a wavelength of $0.15406 \mathrm{~nm}$.

In addition, the morphology, particle size and surface homogeneity of the $\mathrm{LaFe}_{0.7} \mathrm{Mn}_{0.3} \mathrm{O}_{3}$ (optimum catalyst) was studied by scanning electron microscopy (SEM) (MIRA3 FEG-SEM Tescan, Czech).

\subsection{Evaluation of Catalytic performance in CO-SCR process}

The schematic of the setup used to evaluate the activity of the prepared catalysts in the CO-SCR process, is given in Fig. 1. The setup constructed of an electric furnace which is equipped with a temperature control system, plug flow reactor with length of $2 \mathrm{~cm}$ and inner diameter of $0.8 \mathrm{~cm}$ and flow controlling system. Plug flow reactor was connected to a gas chromatograph (Shimadzu, Japan) analyzer equipped with a thermal conductivity detector (TCD) and a HP-Molesieve column $(1=30 \mathrm{~m}$, i.d. = $0.530 \mathrm{~mm}$ ) to analyze the reactants and products.

For each test, gas mixture containing 3000 ppm NO and $3000 \mathrm{ppm} \mathrm{CO}$ in Ar as balance gas with total flow rate of $200 \mathrm{ml} / \mathrm{min}$ was passed through the catalyst. By changing the volume of the catalyst at STP by the constant volumetric flow rate, the space velocity can be obtained as follows [22]:

$$
\text { GHSV }=\frac{V_{\text {exhaust }}}{V_{\text {catalyst }}} \text {. }
$$

Where GHSV is the gas hourly space velocity $(1 / \mathrm{h}), \mathrm{V}_{\text {exhaus }}$ is the volumetric flow rate of the exhaust gas $\left(\mathrm{m}^{3} / \mathrm{h}\right)$, and $\mathrm{V}_{\text {catalyst }}$ is the volume of the catalyst $\left(\mathrm{m}^{3}\right)$. Lowering the space velocity can improve the SCR DeNO $\mathrm{S}_{\mathrm{x}}$ performance because the residence time of the exhaust gas increases, but it may also lead to various problems with the layout of the vehicle installation and may increase costs due to the increased volume of the catalyst [22]. Therefore, to investigate the effect of GHSV on the CO-SCR performance, a series of experiments has been conducted for different space velocity $\left(24000,12000\right.$ and $\left.8000 \mathrm{~h}^{-1}\right)$ in lab-scale plug flow reactor.

The conversion of $\mathrm{NO}$ and $\mathrm{CO}$ were calculated as follows:

$$
\begin{aligned}
& \mathrm{X}_{\mathrm{NO}}=\frac{[\mathrm{NO}]_{\text {in }}-[\mathrm{NO}]_{\text {out }}}{[\mathrm{NO}]_{\text {in }}} \\
& \mathrm{X}_{\mathrm{NO}}=\frac{[\mathrm{CO}]_{\text {in }}-[\mathrm{CO}]_{\text {out }}}{[\mathrm{CO}]_{\text {in }}} .
\end{aligned}
$$

Where $[i]_{\text {in }}$ and $[i]_{\text {out }}$ are concentration of component $i$ at inlet and outlet flow, respectively.

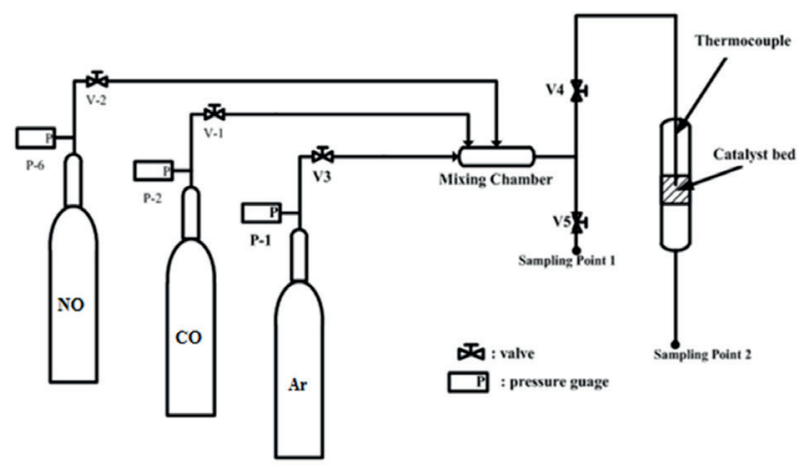

Fig. 1 Schematic diagram of the lab-scale CO-SCR process setup. 


\section{Kinetic modeling of CO-SCR process}

Experiments were performed on the powder catalysts under atmospheric pressure and at different temperatures $\left(100-500{ }^{\circ} \mathrm{C}\right)$ to obtain kinetic parameters of each catalyst. In all experiments, at first the catalyst was heated at $100{ }^{\circ} \mathrm{C}$ for 20 mints to reach the steady-state conditions.

For kinetic modeling of under study process, below mentioned mechanism (Eq. (4)-Eq. (12)) utilized according to Ladavos and coworkers [18, 19, 23]:

$$
\begin{aligned}
& \mathrm{NO} \rightarrow \mathrm{NO}_{\text {ads. }} \\
& \mathrm{NO}_{\text {ads. }} \rightarrow \mathrm{N}_{\text {ads. }}+\mathrm{O}_{\text {ads. }} \\
& \mathrm{CO} \rightarrow \mathrm{CO}_{\text {ads. }} \\
& \mathrm{CO}_{\text {ads. }}+\mathrm{O}_{\text {ads. }} \rightarrow \mathrm{CO}_{2} \\
& 2 \mathrm{~N}_{\text {ads. }} \rightarrow \mathrm{N}_{2} \\
& \mathrm{~N}_{\text {ads. }}+\mathrm{NO}_{\text {ads. }} \rightarrow \mathrm{N}_{2} \mathrm{O}_{\text {ads. }} \\
& \mathrm{N}_{2} \mathrm{O}_{\text {ads. }} \rightarrow \mathrm{N}_{2} \mathrm{O} \\
& \mathrm{N}_{2} \mathrm{O}_{\text {ads. }} \rightarrow \mathrm{N}_{2}+\mathrm{O}_{\text {ads. }} \\
& 2 \mathrm{O}_{\text {ads. }} \rightarrow \mathrm{O}_{2} .
\end{aligned}
$$

These reactions can be expressed by the following two main routes $[16,23]$ :

$$
\begin{aligned}
& \text { A) } 2 \mathrm{NO}+2 \mathrm{CO} \rightarrow \mathrm{N}_{2}+2 \mathrm{CO}_{2} \\
& \text { B) } 2 \mathrm{NO}+\mathrm{CO} \rightarrow \mathrm{N}_{2} \mathrm{O}+\mathrm{CO}_{2}, \mathrm{~N}_{2} \mathrm{O} \rightarrow \mathrm{N}_{2}+\frac{1}{2} \mathrm{O}_{2} \text {. }
\end{aligned}
$$

Pathways A and B (Eq. (13) and Eq. (14)) were considered as the main reactions of process. Three types of kinetic models were selected to describe the behavior of the system, including power low model (PLM), kinetic model 1 (KM1) and kinetic model 2 (KM2).

\subsection{PLM}

Kinetic equations (Eq. (15) and Eq. (16)) for the power law model (PLM) for both of the pathways (A and B) are as followings:

$$
\begin{aligned}
& \mathrm{r}_{1}=\mathrm{k}_{1} \mathrm{C}_{\mathrm{CO}}^{\mathrm{n}_{1}} \mathrm{C}_{\mathrm{NO}}^{\mathrm{m}_{1}} \\
& \mathrm{r}_{2}=\mathrm{k}_{2} \mathrm{C}_{\mathrm{CO}}^{\mathrm{m}_{2}} \mathrm{C}_{\mathrm{NO}}^{\mathrm{n}_{2}} .
\end{aligned}
$$

\subsection{KM1}

In the kinetic model 1 (KM1), the kinetic equations (Eq. (17) and Eq. (18)) for each reaction are expressed as:

$\mathrm{r}_{1}=\mathrm{k}_{1} \mathrm{C}_{\mathrm{NO}} \mathrm{C}_{\mathrm{CO}}$

$\mathrm{r}_{2}=\frac{\mathrm{k}_{2} \mathrm{C}_{\mathrm{NO}} \mathrm{C}_{\mathrm{CO}}}{\left(1+\mathrm{K}_{\mathrm{NO}} \mathrm{C}_{\mathrm{NO}}+\mathrm{K}_{\mathrm{CO}} \mathrm{C}_{\mathrm{CO}}\right)^{2}}$.

\subsection{KM2}

In the kinetic model 2 (KM2), the kinetic equations (Eq. (19) and Eq. (20)) for each reaction are considered as follows:

$$
\begin{aligned}
& \mathrm{r}_{1}=\frac{\mathrm{k}_{1} \mathrm{~K}_{\mathrm{NO}} \mathrm{C}_{\mathrm{NO}} \mathrm{C}_{\mathrm{CO}}}{\left(1+\mathrm{K}_{\mathrm{NO}} \mathrm{C}_{\mathrm{NO}}\right)\left(1+\mathrm{K}_{\mathrm{CO}} \mathrm{C}_{\mathrm{CO}}\right)} \\
& \mathrm{r}_{2}=\frac{\mathrm{k}_{2} \mathrm{~K}_{\mathrm{NO}} \mathrm{C}_{\mathrm{NO}} \mathrm{C}_{\mathrm{CO}}}{\left(\left(1+\mathrm{K}_{\mathrm{NO}} \mathrm{C}_{\mathrm{NO}}\right)\left(1+\mathrm{K}_{\mathrm{CO}} \mathrm{C}_{\mathrm{CO}}\right)\right)^{2}} .
\end{aligned}
$$

In the all discussed kinetic models, reactions rate constants $\left(\mathrm{k}_{\mathrm{i}}\right)$ and adsorption rate constant of equilibrium $\left(\mathrm{K}_{\mathrm{i}}\right)$ were obtained from Arrhenius and Vant Hoff laws, respectively.

$$
\begin{aligned}
& \mathrm{k}_{1}=\mathrm{A}_{1} \exp \left(-\mathrm{E}_{1} / \mathrm{RT}\right) \\
& \mathrm{k}_{2}=\mathrm{A}_{2} \exp \left(-\mathrm{E}_{2} / \mathrm{RT}\right) \\
& \mathrm{K}_{\mathrm{NO}}=\mathrm{A}_{\mathrm{NO}} \exp \left(\Delta \mathrm{H}_{1} / \mathrm{RT}\right) \\
& \mathrm{K}_{\mathrm{CO}}=\mathrm{A}_{\mathrm{CO}} \exp \left(\Delta \mathrm{H}_{2} / \mathrm{RT}\right) .
\end{aligned}
$$

Where $r_{i}$ is the $i^{\text {th }}$ reaction rate, $C i$ is concentration of species $\mathrm{i}$ at gas phase $\left(\mathrm{mol} / \mathrm{m}^{3}\right), \mathrm{K}_{\mathrm{i}}$ is equilibrium constant of adsorption of $\mathrm{NO}$ and $\mathrm{CO}\left(\mathrm{m}^{3} / \mathrm{mol}\right), \mathrm{k}_{\mathrm{i}}$ is rate constant of reduction of $\mathrm{NO}, \mathrm{E}_{\mathrm{i}}$ is activation energy of reaction $\mathrm{i}$ $(\mathrm{KJ} / \mathrm{mol}), \mathrm{A}_{\mathrm{i}}$ is pre-exponential factor of rate constant of reaction

$\mathrm{i} \frac{\left(\left(\mathrm{m}^{3}\right)^{\mathrm{n}_{\mathrm{i}} \mathrm{m}_{\mathrm{i}}} \cdot \mathrm{mol}^{1-\left(\mathrm{n}_{\mathrm{i}}+\mathrm{m}_{\mathrm{i}}\right)}\right)}{\mathrm{gr}_{\text {cat. }} \cdot h r}, \mathrm{hr}=1,2$ and $\frac{\left(\mathrm{m}^{3}\right)^{2}}{\mathrm{~mol} \cdot \mathrm{gr}_{\text {cat. }} \cdot \mathrm{hr}}$

for PLM, KM1 and KM2, respectively. $\mathrm{A}_{\mathrm{NO}}$ and $\mathrm{A}_{\mathrm{CO}}$ are pre-exponential of the equilibrium constant of adsorption of $\mathrm{NO}$ and $\mathrm{CO}\left(\mathrm{m}^{3} / \mathrm{mol}\right), \Delta \mathrm{H}_{\mathrm{i}}$ is enthalpy of absorption reaction of $\mathrm{NO}$ and $\mathrm{CO}(\mathrm{KJ} / \mathrm{mol})$, $\mathrm{R}$ indicates the gas constant $(\mathrm{KJ} / \mathrm{mol} . \mathrm{K})$ and $\mathrm{T}$ is the temperature $(\mathrm{K})$. 


\subsection{Parameters of kinetic models}

The objective function $(\varnothing)$ for estimating the kinetic parameters is equal to the sum of the squared of differences between the theoretical and the experimental conversion (Eq. (25):

$$
\varnothing=\sum_{i=1}^{n} \sum_{j=1}^{m}\left(X_{i j}^{*}-X_{i j}\right)^{2} .
$$

Where $\mathrm{X}_{\mathrm{ij}}{ }^{*}$ is vector of calculated conversion, $\mathrm{X}_{\mathrm{ij}}{ }^{*}$ is vector of measured conversion, $n$ is number of experiments and $\mathrm{m}$ indicates number of variables.

For solving the function equations, ordinary differential equations (ODE 23, Runge-Kutta algorithm) of MATLAB (MATLAB v7.12.0.635) software was used. Then based on the well-known Levenberg - Marquardt (LM) method the parameters were corrected.

\section{Results and discussion 4.1 Catalytic studies}

Results of experimental studies of $\mathrm{NO}$ reduction using $\mathrm{LaFeO}_{3}, \mathrm{LaFe}_{0.7} \mathrm{Mn}_{0.3} \mathrm{O}_{3}$ and $\mathrm{LaMn}_{0.7} \mathrm{Fe}_{0.3} \mathrm{O}_{3}$ at different GHSV's as a function of temperature have been illustrated in Fig. 2 (a)-(c) respectively. Also, conversion curves of CO at the same conditions have been shown in Fig. 2 (d)-(f).
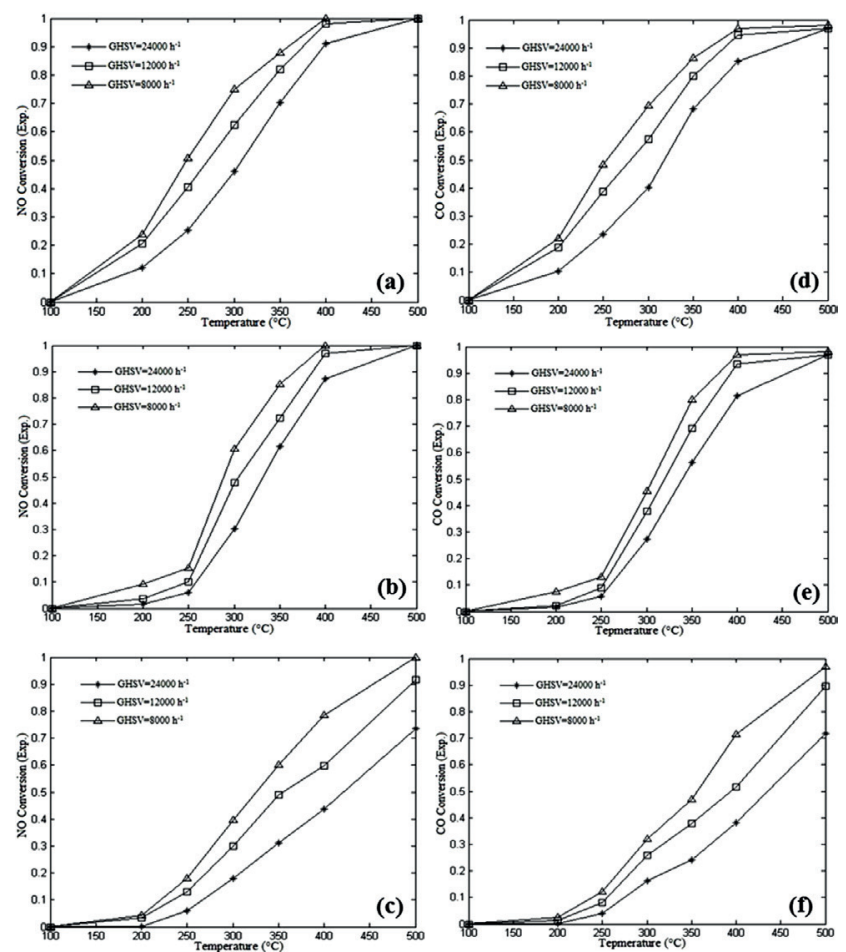

Fig. 2 Effect of operating temperature and GHSV of $\mathrm{LaFe}_{0.7} \mathrm{Mn}_{0.3} \mathrm{O}_{3}$ ((a) and (d)), $\mathrm{LaFeO}_{3}\left((\mathrm{~b})\right.$ and (e)) and $\mathrm{LaMn}_{0.7} \mathrm{Fe}_{0.3} \mathrm{O}_{3}((\mathrm{c})$ and (f)) catalysts on the conversion of $\mathrm{NO}$ and $\mathrm{CO}$ in $\mathrm{CO}-\mathrm{SCR}$ process.
As can be seen from Fig. 2, by increasing the operating temperature and decreasing GHSV conversion of $\mathrm{NO}$ and $\mathrm{CO}$ were improved, because the residence time of the exhaust gas increases. According to these figures when the temperature increased from $200{ }^{\circ} \mathrm{C}$, the reaction rate and conversion of the both pollutants accelerated due to supplying the activation energy at temperatures above $200{ }^{\circ} \mathrm{C}$.

Comparison of Fig. 2 (a) with Fig. 2 (b) and Fig. 2 (d) with Fig. 2 (e) indicate with substitution of manganese and increasing mole fraction of manganese in the $\mathrm{LaFeO}_{3}$ $\left(\mathrm{LaFe}_{0.7} \mathrm{Mn}_{0.3} \mathrm{O}_{3}\right)$ structure, the conversion of $\mathrm{NO}$ and $\mathrm{CO}$ increased. So when iron and manganese there are simultaneously in the $\mathrm{B}$ sites, perovskite catalytic activity improved compared with the case of $\mathrm{LaFeO}_{3}$ which only the iron present at B site. This can be attributed to the synergistic effect between iron and manganese ions [21].

It is observed from Fig. 2 (c) and (f) that the more substitution of manganese in the $\mathrm{B}$ site of perovskite ( $\mathrm{LaMn}_{0.7} \mathrm{Fe}_{0.3} \mathrm{O}_{3}$ ) makes $\mathrm{Mn}$ as dominant $\mathrm{B}$ site ion and as a result decreases $\mathrm{NO}$ and $\mathrm{CO}$ conversion rate due to the decreases of the catalyst activity. So, it is proved that best choice to improve activity, is saving $\mathrm{Fe}$ as dominant $\mathrm{B}$ site ion and partial substitution of that by Mn.

\subsection{Evaluation of kinetic parameters}

In this section, for each model in addition to evaluation of kinetic parameters of CO-SCR process, kinetic model comparison with experimental data carried out and discussed.

\subsubsection{Kinetic parameters in PLM}

Using experimental data and optimization, the values of the PLM parameters (kinetic equations, Eq. (13) and Eq. (14)) are obtained and shown in Table 1.

Comparison between experimental and theoretical data by the power law model of CO-SCR process for each catalyst has been illustrated in Fig. 3. Fig. 3 (b), (e) and (h) compare NO conversion rate using the power law model and experimental data as a function of operating temperature. Also for better evaluation of the conformity between the experimental data and the power law model, comparison between conversion rate of $\mathrm{NO}$ and $\mathrm{CO}$ were performed. As can be seen from Fig. 3 (a), (d) and (g), the results of modeling and experimental study have inappropriate distribution around the line $45^{\circ}$.

According to Fig. 3 (b) and (e), the precision of the model for predictions of the experimental results are high for $\mathrm{LaFeO}_{3}$ and $\mathrm{LaFe}_{0.7} \mathrm{Mn}_{0.3} \mathrm{O}_{3}$ catalysts at GHSV of $24000 \mathrm{~h}^{-1}$. But this model is not suitable for performance prediction of 
Table 1 Kinetic parameters of the PLM, KM1, and KM2 in the CO-SCR process in the region of $100-500{ }^{\circ} \mathrm{C}$.

\begin{tabular}{|c|c|c|c|c|c|c|c|c|c|}
\hline \multirow{2}{*}{$\begin{array}{l}\text { Kinetic } \\
\text { parameters }\end{array}$} & \multicolumn{3}{|c|}{$\mathrm{LaFeO}_{3}$} & \multicolumn{3}{|c|}{$\mathrm{LaFe}_{0.7} \mathrm{Mn}_{0.3} \mathrm{O}_{3}$} & \multicolumn{3}{|c|}{$\mathrm{LaMn}_{0.7} \mathrm{Fe}_{0.3} \mathrm{O}_{3}$} \\
\hline & PLM & KM1 & KM2 & PLM & KM1 & KM2 & PLM & KM1 & KM2 \\
\hline $\mathrm{A}_{1}$ & $8.56^{\times} 10^{4}$ & $2.314^{\times} 10^{10}$ & 204.025 & $5.26^{\times} 10^{4}$ & $6.206^{\times} 10^{7}$ & 654.227 & $7.93 \times 10^{4}$ & $6.078^{\times} 10^{4}$ & 854.227 \\
\hline $\mathrm{A}_{2}$ & 745.307 & 6.949 & 0.113 & 295.307 & 58.858 & 0.023 & 1.052 & 368.497 & 0.033 \\
\hline $\mathrm{E}_{1}$ & 66.853 & 85.783 & 75.752 & 62.853 & 53.348 & 44.052 & 49.876 & 64.741 & 52.114 \\
\hline $\mathrm{E}_{2}$ & 35.063 & 22.039 & 2.137 & 32.063 & 2.454 & 1.937 & 26.541 & 3.401 & 2.182 \\
\hline $\mathrm{m}_{1}$ & 0.112 & 85.783 & 75.752 & 0.169 & 53.348 & 52.114 & 0.887 & 64.741 & 44.052 \\
\hline $\mathrm{m}_{2}$ & 1.141 & 22.039 & 2.137 & 1.051 & 2.454 & 2.182 & 0.146 & 3.401 & 1.937 \\
\hline $\mathrm{n}_{1}$ & 0.977 & 110.620 & 39.065 & 0.947 & 66.214 & 35.701 & 0.701 & 64.921 & 38.065 \\
\hline $\mathrm{n}_{2}$ & 0.263 & 7.130 & 9.959 & 0.213 & 49.738 & 7.432 & 0.846 & 51.738 & 8.632 \\
\hline $\mathrm{A}_{\mathrm{NO}}$ & & $1.312^{\times} 10^{-5}$ & 21.000 & & $1.677^{\times} 10^{-3}$ & 88.762 & & $2.077^{\times 10^{-3}}$ & 75.762 \\
\hline $\mathrm{A}_{\mathrm{CO}}$ & & $1.739 \times 10^{-5}$ & 0.0211 & & $6.019^{\times} 10^{-3}$ & 19.198 & & $8.130^{\times} \times 10^{-3}$ & 15.552 \\
\hline$\Delta \mathrm{H}_{1}$ & & 110.620 & 39.065 & & 66.214 & 38.065 & & 64.921 & 35.701 \\
\hline$\Delta \mathrm{H}_{2}$ & & 7.130 & 9.959 & & 49.738 & 8.632 & & 51.738 & 7.432 \\
\hline
\end{tabular}

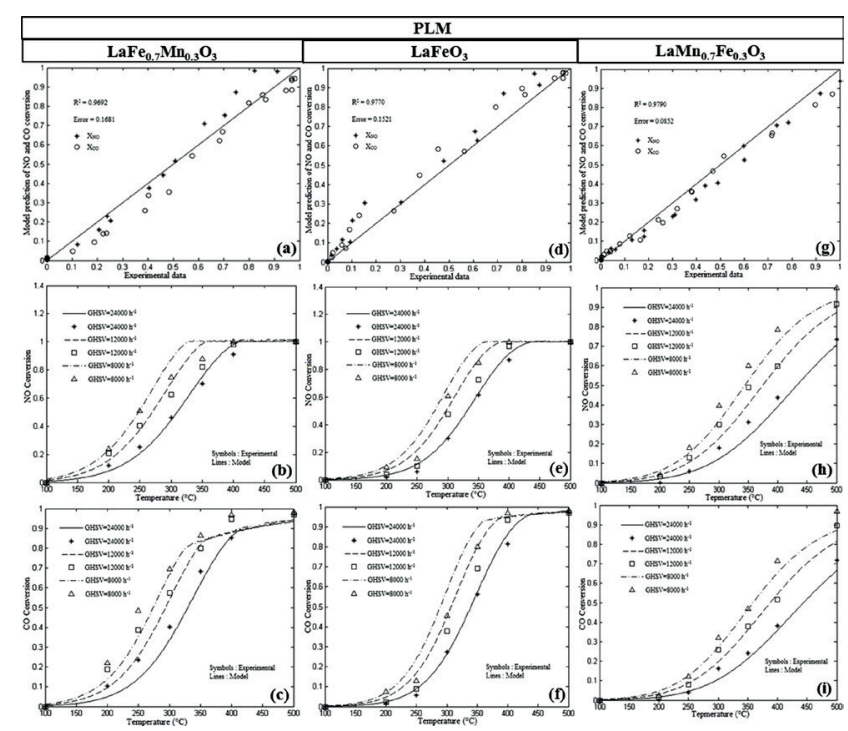

Fig. 3 (a), (d), (g) NO and CO conversion obtained from the power law model and experimental results for each catalyst, (b), (e), (h) effect of operating temperature and GHSV of each catalyst on experimental (symbols) and simulated (lines) NO conversion, and (c), (f), (i) effect of operating temperature and GHSV of each catalyst on experimental (symbols) and simulated (lines) $\mathrm{CO}$ conversion rate in $\mathrm{CO}-\mathrm{SCR}$ process.

$\mathrm{LaFeO}_{3}$ and $\mathrm{LaFe}_{0.7} \mathrm{Mn}_{0.3} \mathrm{O}_{3}$ catalysts at GHSV of 12000 and $8000 \mathrm{~h}^{-1}$. This model showed correlation coefficient value of 0.9790 and squared error of 0.0852 for $\mathrm{LaMn}_{0.7} \mathrm{Fe}_{0.3} \mathrm{O}_{3}$ and so, has good precision only for prediction of the experimental results about $\mathrm{LaMn}_{0.7} \mathrm{Fe}_{0.3} \mathrm{O}_{3}$ for each GHSV.

\subsubsection{KM1}

Using experimental data and optimization, the parameters of KM1 (kinetic equations Eq. (14) and Eq. (15) for the perovskite catalysts are given in Table 1 .
The comparisons between experimental and theoretical data of KM1 for CO-SCR process are shown in Fig. 4 for each catalyst. Fig. 4 (b), (e) and (h) show the NO conversion rate obtained from KM1 and experimental values as a function of operating temperature. This model showed correlation coefficient values of $0.9911,0.9924$ and 0.9902 and squared errors of $0.0488,0.0504$ and 0.0397 respectively for $\mathrm{LaFe}_{0.7} \mathrm{Mn}_{0.3} \mathrm{O}_{3}, \mathrm{LaFeO}_{3}$ and $\mathrm{LaMn}_{0.7} \mathrm{Fe}_{0.3} \mathrm{O}_{3}$. Therefore this model could predict the CO-SCR process with considerable precision. For good evaluation of the conformity between the experimental data and simulated results by $\mathrm{KM}$, comparison between conversion rate of $\mathrm{NO}$ and $\mathrm{CO}$ were performed. As can be seen from Fig. 4 (a), (d) and (g), the results of modeling and experimental study have good distribution around the line $45^{\circ}$ and shows the KM1 have reasonable ability for prediction of process kinetics.

\subsubsection{KM2}

Using experimental data and optimization, the parameters of KM2 (kinetic equations Eq. (16) and Eq. (17)) for the perovskite catalysts are given in Table 1 .

Comparison of experimental and theoretical results of KM2 is given in Fig. 5. According to Fig. 5 (b), (e) and (h) which illustrate the NO conversion rate from KM2 and experimental results as a function of temperature. As can be seen from Fig. 5 (a), (d) and (g), this model showed correlation coefficient values of $0.9858,0.9873$ and 0.9814 and squared errors of $0.0775,0.0841$ and 0.0754 respectively for $\mathrm{LaFe}_{0.7} \mathrm{Mn}_{0.3} \mathrm{O}_{3}, \mathrm{LaFeO}_{3}$ and $\mathrm{LaMn}_{0.7} \mathrm{Fe}_{0.3} \mathrm{O}_{3}$. Therefor this model has higher precision than the power law model for prediction of the experimental results. Compared to 


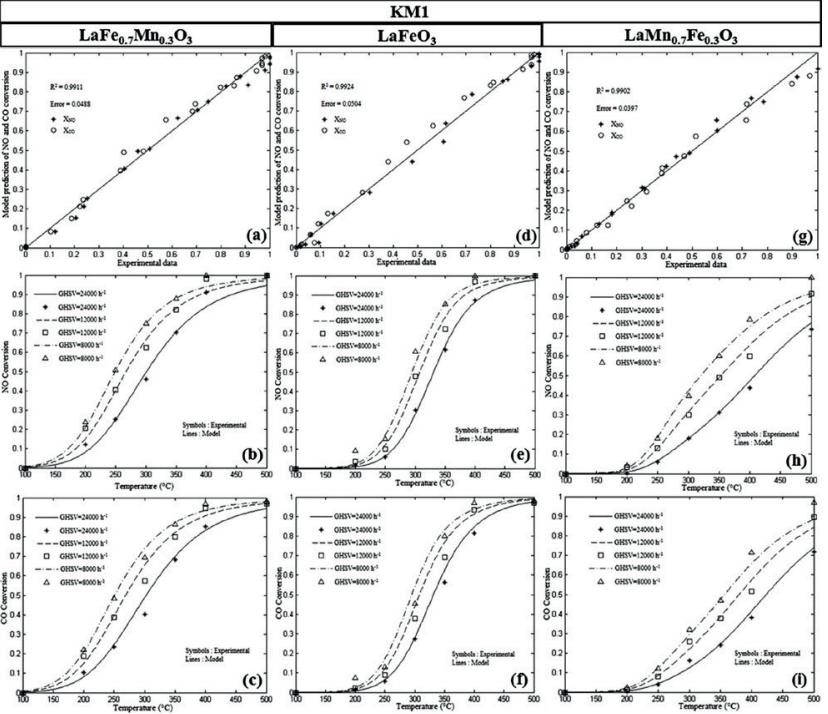

Fig. 4 (a), (d), (g) NO and CO conversion obtained from the KM1 and experimental results for each catalyst, (b), (e), (h) effect of operating temperature and GHSV of each catalyst on experimental (symbols) and simulated (lines) NO conversion, and (c), (f), (i) effect of operating temperature and GHSV of each catalyst on experimental (symbols) and simulated (lines) $\mathrm{CO}$ conversion rate in $\mathrm{CO}-\mathrm{SCR}$ process

KM1, KM2 doesn't have acceptable fit to the experimental data especially at higher temperatures.

For evaluation of the models for each perovskite catalyst in CO-SCR process the bar graphs of correlation coefficients and the sum of squared errors were used. Comparing these figures (Fig. 6 (a)-(f)) confirm the KM1 has better fitness with the experimental data than KM2 and PLM. So the KM1 is selected as the best model for prediction of the CO-SCR process on the perovskite catalyst.

\subsection{Catalysts characterization}

The XRD patterns of the catalysts summarized in Fig. 7. Comparison of XRD patterns of synthesized $\mathrm{LaFeO}_{3}$ and its standard peak (ICSD 084941 card) indicated that there is good conformity between diffraction pattern of synthesized $\mathrm{LaFeO}_{3}$ and the standard data. The mentioned standard structure has orthorhombic structure. This result approves the synthesis of $\mathrm{LaFeO}_{3}$ and indicates the single phase perovskite with orthorhombic structure. The average crystallite sizes of the perovskite using Scherer equation (Eq. (26)) considering the sharpest peak is given at Table 2.

$d=\frac{K \lambda}{\beta \cos \theta}$.

Where $\mathrm{d}(\mathrm{nm})$ is the crystallite size, $\theta$ is the Bragg angle, $K$, is the constant of diffraction (0.89), $\lambda(0.154056 \mathrm{~nm})$, is the X-ray wavelength and $\beta$ is the peak width at the half-maximum, corrected for instrument broadening.

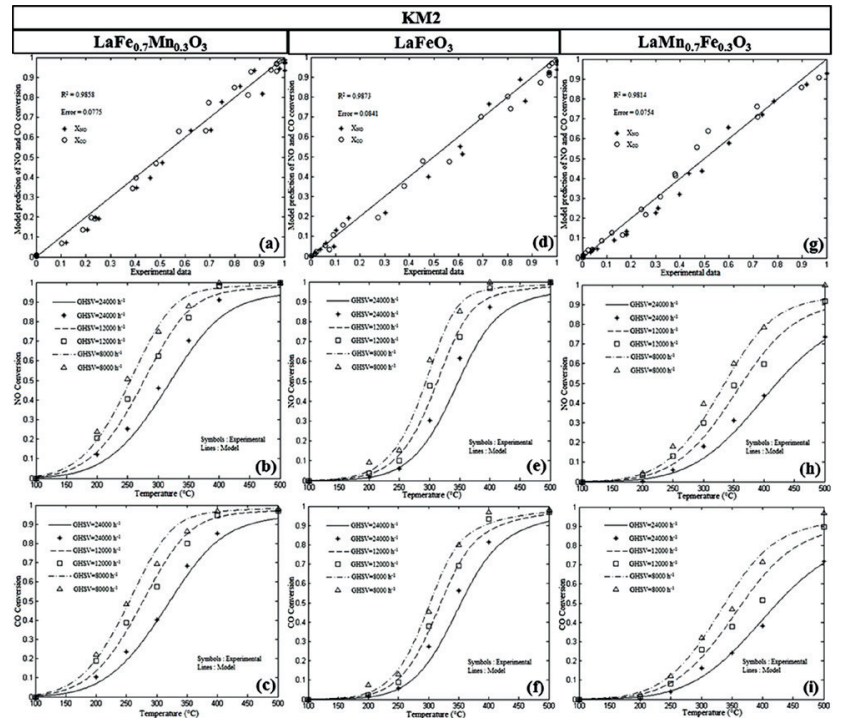

Fig. 5 (a), (d), (g) NO and CO conversion obtained from the KM2 and experimental results for each catalyst, (b), (e), (h) effect of operating temperature and GHSV of each catalyst on experimental (symbols) and simulated (lines) NO conversion, and (c), (f), (i) effect of operating temperature and GHSV of each catalyst on experimental (symbols) and simulated (lines) $\mathrm{CO}$ conversion rate in CO-SCR process.

Fig. 7 (a) shows XRD patterns of synthesized $\mathrm{LaFe}_{0.7} \mathrm{Mn}_{0.3} \mathrm{O}_{3}$ and $\mathrm{LaFeO}_{3}$ and also, their main peaks with magnification. The synthesized catalyst shows orthorhombic structure similar to the structure of the $\mathrm{LaFeO}_{3}$. A slight shift to the right in the main peak of diffraction pattern of the modified catalyst $\left(\mathrm{LaFe}_{0.7} \mathrm{Mn}_{0.3} \mathrm{O}_{3}\right)$ can be seen. This is because of the introduction of Mn in the crystallite structure of $\mathrm{LaFeO}_{3}$ which changes the unit cell size. In fact, this is due to the unequal ionic radius of Fe and Mn. Which, in turn, changes the size of the unit cell. It appears by changing the distance between the plates and therefore the peak in the XRD pattern. Such changes demonstrate the entrance of Mn into the structure. However, as can be seen, there is good agreement in the diffraction patterns of the modified catalyst and standard pattern and such an

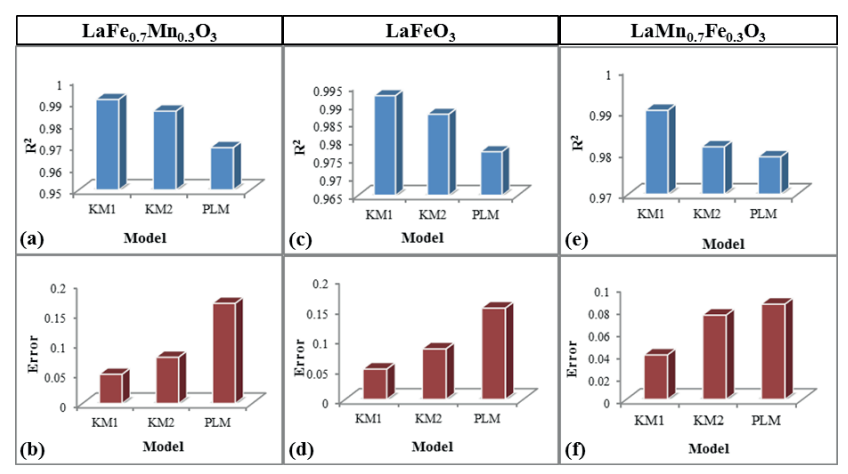

Fig. 6 (a), (c), (e) Correlation coefficients and (b), (d), (f) Sum of squared errors of kinetic models for CO-SCR process on the $\mathrm{LaFe}_{0.7} \mathrm{Mn}_{0.3} \mathrm{O}_{3}, \mathrm{LaFeO}_{3}, \mathrm{LaMn}_{0.7} \mathrm{Fe}_{0.3} \mathrm{O}_{3}$ catalyst. 
Table 2 Crystallite size of catalysts based on $\mathrm{XRD}$ analysis and Scherer equation.

\begin{tabular}{lc}
\hline Catalyst & Crystallite size (nm) \\
\hline $\mathrm{LaFeO}_{3}$ & 27 \\
$\mathrm{LaFe}_{0.7} \mathrm{Mn}_{0.3} \mathrm{O}_{3}$ & 16 \\
$\mathrm{LaMn}_{0.7} \mathrm{Fe}_{0.3} \mathrm{O}_{3}$ & 15 \\
\hline
\end{tabular}

agreement proves that the synthesized catalyst has the orthorhombic structure.

XRD pattern of $\mathrm{LaMn}_{0.7} \mathrm{Fe}_{0.3} \mathrm{O}_{3}$ and standard XRD pattern of $\mathrm{LaMnO}_{3}$ (01-086-1228.CAF card) have been depicted in Fig. 7 (b). XRD of $\mathrm{LaMn}_{0.7} \mathrm{Fe}_{0.3} \mathrm{O}_{3}$ is consistent with the standard XRD of $\mathrm{LaMnO}_{3}$ and approves the synthesis and rhombohedral structure of the prepared catalyst. For better comparison and to prove the introduction of the iron ion in the $\mathrm{LaMnO}_{3}$, the main peak of XRD patterns of the synthesized $\mathrm{LaMn}_{0.7} \mathrm{Fe}_{0.3} \mathrm{O}_{3}$ and standard $\mathrm{LaMnO}_{3}$ are shown with more magnification. A slight shift to the right hand side in the diffraction pattern of the modified catalyst can be seen. This is due to the substitution of Fe in the B site of the crystallite structure of $\mathrm{LaMnO}_{3}$. By introduction of Fe to the Mn perovskite, its rhombohedral structure is preserved but each of the peaks shifted as a result of change in cell size due to the presence of ions with different sizes and thereby changing the distance between the planes slightly. This change confirms the presence of the iron ion in the structure of manganese perovskite.

Based on Scherer equation and XRD pattern of each catalyst, crystallite size of them were calculated and summarized in Table 2. According these calculations, size of catalysts crystallites are below $30 \mathrm{~nm}$.

Fig. 8 shows the SEM image of the optimum catalyst $\left(\mathrm{LaFe}_{0.7} \mathrm{Mn}_{0.3} \mathrm{O}_{3}\right.$ ). According to this figure the morphology of the particles are spherical approximately and some of
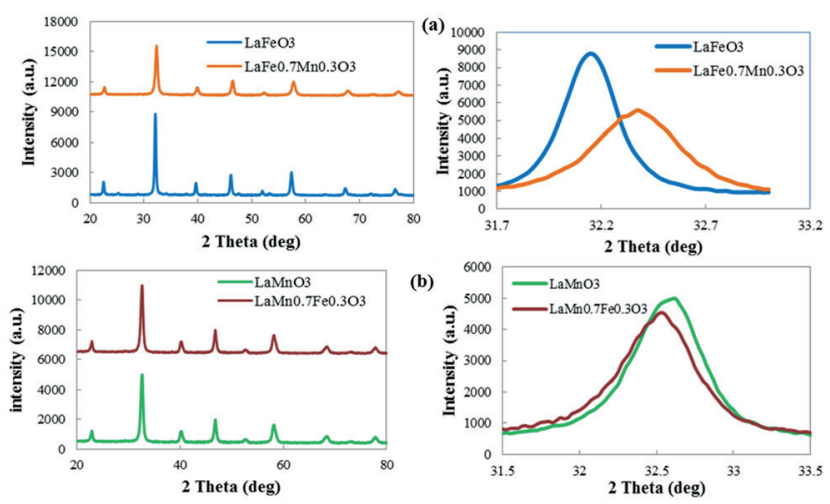

Fig. $7 \mathrm{XRD}$ profiles of synthesized $\mathrm{LaFe}_{0.7} \mathrm{Mn}_{0.3} \mathrm{O}_{3}$ and $\mathrm{LaFeO}_{3}$ (a), and XRD profiles of synthesized $\mathrm{LaMn}_{0.7} \mathrm{Fe}_{0.3} \mathrm{O}_{3}$ and standard pattern of LaMnO3 (01-086-1228.CAF card) (b) them are as irregular shaped grains. Most of particles have sizes less than $100 \mathrm{~nm}$ are observed in the image.

\section{Conclusion}

In this research $\mathrm{LaFeO}_{3}, \mathrm{LaFe}_{0.7} \mathrm{Mn}_{0.3} \mathrm{O}_{3}$ and $\mathrm{LaMn}_{0.7} \mathrm{Fe}_{0.3} \mathrm{O}_{3}$ perovskite nanocatalysts were prepared by sol-gel method successfully. The catalysts were used for reducing NO emission using $\mathrm{CO}$ while the reduction process was performed in the plug flow reactor. Experimental results indicate by substitution of manganese in the $\mathrm{B}$ site of the $\mathrm{LaFeO}_{3}$ catalyst, the conversion rate of $\mathrm{NO}$ and $\mathrm{CO}$ was increased due to the synergistic effect between manganese and iron. But, Iron and manganese in the structure of perovskite should have an optimized stoichiometric ratio for good performance. The $\mathrm{LaFe}_{0.7} \mathrm{Mn}_{0.3} \mathrm{O}_{3}$ showed good activity than other catalysts.

To investigate the effect of GHSV on the CO-SCR performance, a series of experiments was conducted for different space velocity $\left(24000,12000\right.$ and $\left.8000 \mathrm{~h}^{-1}\right)$. The results indicated that conversion of $\mathrm{NO}$ and $\mathrm{CO}$ improved by increasing the operating temperature and decreasing GHSV, which can be attributed to the increase in the residence time of the exhaust gas.

In this work, in addition to studying the function of synthesized catalysts and finding the optimal catalyst in the CO-SCR process, according to the process mechanism, three new mechanical models were proposed for this process for the first time and According to the obtained results, our models can predict the experimental data with

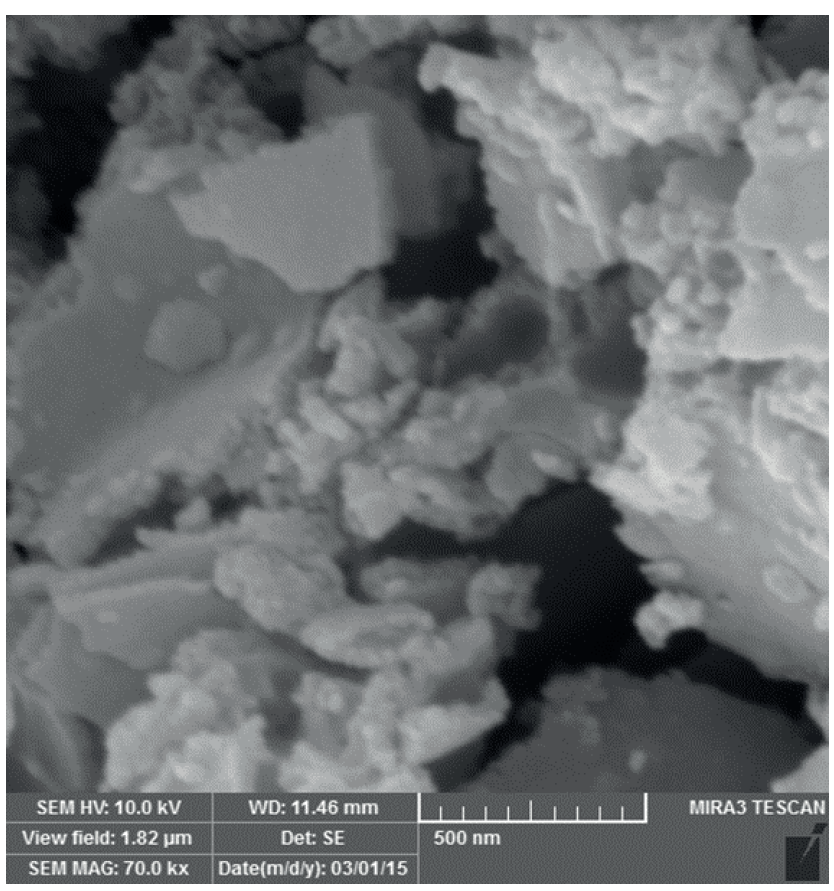

Fig. 8 SEM image of $\mathrm{LaFe}_{0.7} \mathrm{Mn}_{0.3} \mathrm{O}_{3}$ catalyst. 
a good accuracy. This study shows that one of the reported new models can successfully be used for prediction of catalyst activity in CO-SCR. The model KM1 with correlation coefficients of $0.9924,0.9911$ and 0.9902 and sum of

\section{References}

[1] Perera, F. "Pollution from Fossil-Fuel Combustion is the Leading Environmental Threat to Global Pediatric Health and Equity: Solutions Exist", International Journal of Environmental Research and Public Health, 15(1), pp. 1-16, 2018.

https://doi.org/10.3390/ijerph15010016

[2] Sharma, S. B., Jain, S., Khirwadkar, P., Kulkarni, S. "The effects of air pollution on the environment and human health", Indian Journal of Research in Pharmacy and Biotechnology, 1(3), pp. 391396, 2013. [online] Available at: http://www.ijrpb.com/issues/ Volume\%201_Issue\%203/ijrpb\%201(3)\%2020\%20page\%20391396.pdf [Accessed: 01 May 2013]

[3] Colls, J. "Air Pollution", 2nd ed., Spon Press, London, UK, 2002.

[4] Batrakov, P., A. "The nitrogen oxide formation studying at natural gas combustion in non-circular profile furnaces of fire-tube boilers", Procedia Engineering, 152, pp. 144-150, 2016.

https://doi.org/10.1016/j.proeng.2016.07.646

[5] Amanpour, J., Salari, D., Niaei, A., Mousavi, S. M., Nakhostin Panahi, P. "Optimization of $\mathrm{Cu}$ /activated carbon catalyst in low temperature selective catalytic reduction of NO process using response surface methodology", Journal of Environmental Science and Health, 48(8), pp. 879-886, 2013.

https://doi.org/10.1080/10934529.2013.761490

[6] Sher, E. "Handbook of air pollution from internal combustion engines: pollutant formation and control", 1st ed., Academic Press, San Diego, USA, 1998.

[7] Olsen, D. B., Kohls, M., Arney, G. "Impact of Oxidation Catalysts on Exhaust $\mathrm{NO}_{2} / \mathrm{NO}_{x}$ Ratio from Lean-Burn Natural Gas Engines", Journal of the Air \& Waste Management Association, 60(7), pp. 867-874, 2010.

https://doi.org/10.3155/1047-3289.60.7.867

[8] Ertl, G., Knozinger, H., Weitkamp, J. "Environmental Catalysis", 1st ed., Wiley-VCH, Weinheim FRG, Germany, 1999.

[9] Gomez-Garcia, M. A., Pitchon, V., Kiennemann, A. "Pollution by nitrogen oxides: an approach to $\mathrm{NO}_{\mathrm{x}}$ abatement by using sorbing catalytic materials", Environment International, 31(3), pp. 445-467, 2005.

https://doi.org/10.1016/j.envint.2004.09.006

[10] Meyers, R. A., Dittrick, D. K. "Encyclopedia of Environmental Pollution and Cleanup", Wiley, New York, USA, 1999.

[11] Ravishankara, A. R. "Introduction: atmospheric chemistry longterm issues", Chemical Reviews, 103, pp. 4505-4508, 2003. https://doi.org/10.1021/cr020463i

[12] Oertel, C., Matschullat, J., Zurba, K., Zimmermann, F., Erasmi, S. "Greenhouse gas emissions from soils - A review", Geochemistry, 76(3), pp. 327-352, 2016.

https://doi.org/10.1016/j.chemer.2016.04.002

[13] He, H., Liu, M., Dai, H., Qiu, W., Zi, X. "An investigation of NO/ $\mathrm{CO}$ reaction over perovskite-type oxide $\mathrm{La}_{0.8} \mathrm{Ce}_{0.2} \mathrm{~B}_{0.4} \mathrm{Mn}_{0.6} \mathrm{O}_{3}$ (B $=\mathrm{Cu}$ or $\mathrm{Ag}$ ) catalysts synthesized by reverse microemulsion", Catalysis Today, 126(3-4), pp. 290-295, 2007. https://doi.org/10.1016/j.cattod.2007.06.004 squared errors of $0.0504,0.0488$ and 0.0397 respectively for $\mathrm{LaFeO}_{3}, \mathrm{LaFe}_{0.7} \mathrm{Mn}_{0.3} \mathrm{O}_{3}$ and $\mathrm{LaMn}_{0.7} \mathrm{Fe}_{0.3} \mathrm{O}_{3}$ catalysts was the best model for prediction of the CO-SCR process using the synthesized perovskite catalyst.

[14] Piumetti, M., Bensaid, S., Fino, D., Russo, N. "Catalysis in Diesel engine NOx aftertreatment: a review, Catalysis, Structure \& Reactivity", 1(4), pp. 155-173, 2015. https://doi.org/10.1080/2055074X.2015.1105615

[15] Leontiou, A. A., Ladavos, A. K., Pomonis, P. J. "Catalytic NO reduction with $\mathrm{CO}$ on $\mathrm{La}_{1-\mathrm{x}} \mathrm{Sr}_{\mathrm{x}}\left(\mathrm{Fe}^{3+} / \mathrm{Fe}^{4+}\right) \mathrm{O}_{3 \pm \delta}$ perovskite-type mixed oxides $(\mathrm{x}=0.00,0.15,0.30,0.40,0.60,0.70,0.80$, and 0.90$) "$, Applied Catalysis A: General, 241(1-2), pp. 133-141, 2003. https://doi.org/10.1016/S0926-860X(02)00457-X

[16] Giannakas, A. E., Ladavos, A. K., Pomonis, P. J. "Preparation, characterization and investigation of catalytic activity for $\mathrm{NO}+\mathrm{CO}$ reaction of $\mathrm{LaMnO}_{3}$ and $\mathrm{LaFeO}_{3}$ perovskites prepared via microemulsion method", Applied Catalysis B: Environmental, 49(3), pp. 147-158, 2004.

https://doi.org/10.1016/j.apcatb.2003.12.002

[17] Kumar, S., Teraoka, Y., Joshi, A. G., Rayalu, S., Labhsetwar, N. "Ag promoted $\mathrm{La}_{0.8} \mathrm{Ba}_{0.2} \mathrm{MnO}_{3}$ type perovskite catalyst for $\mathrm{N}_{2} \mathrm{O}$ decomposition in the presence of $\mathrm{O}_{2}, \mathrm{NO}$ and $\mathrm{H}_{2} \mathrm{O}$ ", Journal of Molecular Catalysis A: Chemical, 348(1-2), pp. 42-54, 2011. https://doi.org/10.1016/j.molcata.2011.07.017

[18] Zhu, J., Thomas, A. "Perovskite-type mixed oxides as catalytic material for NO removal", Applied Catalysis B: Environmental, 92(3-4), pp. 225-233, 2009.

https://doi.org/10.1016/j.apcatb.2009.08.008

[19] Leontiou, A. A., Ladavos, A. K., Armatas, G. S., Trikalitis, P. N., Pomonis, P. J. "Kinetics investigation of $\mathrm{NO}+\mathrm{CO}$ reaction on $\mathrm{La}-$ $\mathrm{Sr}-\mathrm{Mn}-\mathrm{O}$ perovskite-type mixed oxides", Applied Catalysis A: General, 263(2), pp. 227-239, 2004. https://doi.org/10.1016/j.apcata.2003.12.017

[20] Pena, M. A., Fierro, J. L. G. "Chemical structures and performance of perovskite oxides", Chemical Reviews, 101(7), pp. 1981-2018, 2001.

https://doi.org/10.1021/cr980129f

[21] Arefi Oskoui, S., Niaei, A., Tseng, H-H., Salari, D., Izadkhah, B., Hosseini, S. A. "Modeling Preparation Condition and CompositionActivity Relationship of Perovskite-Type $\mathrm{La}_{\mathrm{x}} \mathrm{Sr}_{1-\mathrm{x}} \mathrm{Fe}_{\mathrm{y}} \mathrm{Co}_{1-\mathrm{y}} \mathrm{O}_{3}$ Nano Catalyst", ACS Combinatorial Science, 15(12), pp. 609-621, 2013. https://doi.org/10.1021/co400017r

[22] Yun, B. K., Kim, M. Y. "Modeling the selective catalytic reduction of $\mathrm{NO}_{\mathrm{x}}$ by ammonia over a Vanadia-based catalyst from heavy duty diesel exhaust gases", Applied Thermal Engineering, 50(1), pp. 152-158, 2013.

https://doi.org/10.1016/j.applthermaleng.2012.05.039

[23] Ladavos, A. K., Pomonis, P. J. "Mechanistic aspects of $\mathrm{NO}+\mathrm{CO}$ reaction on $\mathrm{La}_{2-\mathrm{x}} \mathrm{Sr}_{\mathrm{x}} \mathrm{NiO}_{4-\delta}(\mathrm{x}=0.00-1.50)$ perovskite-type oxides", Applied Catalysis A: General, 165(1-2), pp. 73-85, 1997. https://doi.org/10.1016/S0926-860X(97)00192-0 